\title{
Analisis faktor-faktor yang mempengaruhi pengangguran terbuka di Provinsi Jambi
}

\author{
*Rhivna Cilviyani Rambe; Purwaka Hari Prihanto; Hardiani
}

Prodi Ekonomi Pembangunan, Fakultas Ekonomi dan Bisnis, Universitas Jambi

*E-mail korespodensi: Rhivnacilviyani193@gmail.com

\begin{abstract}
The research as purpose: (1) To find out and analysis the development of open unemployment rates in Jambi Province; and (2) What factors influence open unemployment in Jambi Province. The method used in this study is descriptive analysis and quantitative analysis, namely multiple linier regression using data from 2000-2017. The results of this study indicate: (1) The average development of open unemployment in Jambi Province is 0,53 percent; (2) The results of data analysis show that during the period 2000-2017 GDP, wages, inflation, and investment had a positive and significant effect on open unemployment in Jambi Province. A level of labor force participation does not significantly influence open unemployment in Jambi Province.
\end{abstract}

Keyword: Open Unemployment, Wages, Inflation, Investment, and Labor Force Participation Rates.

\begin{abstract}
Abstrak
Penelitian ini bertujuan: (1) Untuk mengatahui dan menganalisis perkembangan tingkat pengangguran terbuka di Provinsi Jambi; dan (2) Faktor-faktor apa yang mempengaruhi pengangguran terbuka di Provinsi Jambi. Metode yang digunakan dalam penelitian ini adalah analisis deskriptif dan analisis kuantitatif yaitu regresi linier berganda dengan menggunakan data tahun 2000-2017. Hasil penelitian ini menunjukkan: (1) Rata-rata perkembangan pengangguran terbuka di Provinsi Jambi sebesar 0,53 persen; (2) Hasil analisis menunjukkan bahwa PDRB, upah minimum, inflasi, dan investasi berpengaruh signifikan terhadap pengangguran terbuka di Provinsi Jambi. Sedangkan tingkat partisipasi angkatan kerja tidak berpengaruh signifikan terhadap pengangguran terbuka di Provinsi Jambi.
\end{abstract}

Kata Kunci: Pengangguran Terbuka, PDRB, Upah, Inflasi, Investasi, dan TPAK.

\section{PENDAHULUAN}

Pengangguran merupakan suatu fenomena yang terjadi disemua negara berkembang tidak terkecuali di Indonesia. Menurut Nanga (2001), pengangguran adalah suatu keadaan dimana seseorang yang tergolong dalam angkatan kerja tidak memiliki pekerjaan dan secara aktif sedang mencari pekerjaan. Pengangguran meliputi penduduk yang sedang mencari pekerjaan, atau mempersiapkan suatu usaha atau merasa tidak mungkin mendapatkan pekerjaan, atau sudah mempunyai pekerjaan tetapi belum mulai bekerja (BPS, 2016).

Pengangguran terjadi karena pertumbuhan angkatan kerja lebih tinggi dari pertumbuhan lapangan pekerjaan yang ada. Pengangguran merupakan salah satu indikator penting dibidang ketenagakerjaan, dimana tingkat pengangguran dapat mengukur sejauh mana angkatan kerja mampu diserap oleh lapangan kerja yang ada. Pengangguran yang tinggi dapat menjadi sumber utama kemiskinan, dapat memicu 
kriminalitas yang tinggi serta dapat menghambat pembangunan dalam jangka panjang (Artriyan, 2013).

Pengangguran terbuka atau tuna karya adalah istilah untuk orang yang tidak bekerja sama sekali, sedang mencari kerja, bekerja kurang dari dua hari selama seminggu, atau seseorang yang sedang berusaha mendapatkan pekerjaan yang layak. Pengangguran terbuka umumnya disebabkan karena jumlah angkatan kerja atau para pencari kerja tidak sebanding dengan jumlah lapangan kerja yang ada yang mampu menyerapnya. Pengangguran terbuka sering kali menjadi masalah dalam perekonomian, karena dengan adanya pengangguran terbuka, produktivitas dan pendapatan masyarakat akan berkurang sehingga dapat menyebabkan timbulnya kemiskinan dan masalah-masalah sosial lainnya.

Pengangguran terbuka memang kini belum bisa terlepaskan dari salah satu bagian masalah yang dihadapi oleh negara-negara berkembang di dunia, termasuk bangsa Indonesia. Pengangguran terbuka di negeri ini, masih menjadi masalah aktual yang menjadi bahasan panjang sejak orde baru tumbang dan Indonesia dicap sebagai negara yang cukup terganggu perkembangan perekonomiannya. Salah satu tujuan pembangunan nasional adalah untuk meningkatkan kesejahteraan masyarakat. Indonesia sebagai negara berkembang harus melakukan banyak perubahan untuk mendukung pembangunan nasional. Hal tersebut bertujuan agar terciptanya stabilitas nasional, iklim investasi yang baik, dan pertumbuhan ekonomi yang tinggi sehingga dapat menekan angka pengangguran terbuka di Indonesia. Terdapat beberapa faktor yang dapat mempengaruhi tingkat pengangguran terbuka diantaranya faktor-faktor yang mempengaruhi pengangguran terbuka adalah pertumbuhan ekonomi, upah, inflasi, dan investasi.

Di Provinsi Jambi Pengangguran terbuka merupakan salah satu masalah yang kompleks karena dapat dipengaruhi dan mempengaruhi oleh banyak faktor yang saling berinteraksi. Apabila pengangguran terbuka tersebut tidak segera diatasi maka akan menimbulkan kerawanan sosial dan berpotensi mengakibatkan ketimpangan baik dari segi sosial maupun ekonomi. Besarnya angka pengangguran di Provinsi Jambi dapat dikatakan sangat penting dalam mengukur keberhasilan pembangunan ekonomi. Hal ini dikarenakan pengangguran merupakan salah satu indikator untuk menunjukan tingkat kesejahteraan akibat dari pembangunan ekonomi.

Selama periode tahun 2000-2017 pengangguran terbuka di Provinsi jambi bersifat fluktuatif. Pada periode 5 tahun terakhir, yaitu pada tahun 2013 jumlah pengangguran terbuka di Provinsi Jambi mencapai 4,84\%. kemudian pada tahun 2014 jumlah pengangguran terbuka di Provinsi Jambi mengalami kenaikan yaitu sebesar $5,08 \%$, selanjutnya pada tahun 2015 jumlah pengangguran terbuka di Provinsi Jambi mengalami penurunan sebesar 4,34\%, selanjutnya pada tahun 2016 jumlah pengangguran terbuka mengalami penurunan pada sebesar 4,00\%, dan pada tahun 2017 jumlah pengangguran terbuka di Provinsi Jambi mengalami penurunan kembali yaitu sebesar $3,87 \%$.

Produk Domestik Regional Bruto menurut Badan Pusat Statistik (BPS) didefinisikan sebagai jumlah nilai tambah yang dihasilkan oleh seluruh unit usaha dalam suatu wilayah, atau merupakan jumlah seluruh nilai barang dan jasa akhir yang dihasilkan oleh seluruh unit ekonomi di suatu wilayah. PDRB dapat mengambarkan kemampuan suatu daerah mengelola sumber daya alam yang dimilikinya. Oleh karena itu, besaran PDRB yang dihasilkan oleh masing-masing daerah sangat bergantung 
kepada potensi faktor-faktor produksi di daerah tersebut. Adanya keterbatasan dalam penyediaan faktor-faktor produksi tersebut menyebabkan besaran PDRB bervariasi antar daerah.

Pada periode 5 tahun terkahir, 2013-2017 PDRB di Provinsi Jambi mengalami kenaikan pada setiap tahunnya. Pada tahun 2013 PDRB Provinsi Jambi mencapai angka sebesar 21.979.277 juta rupiah, tahun 2014 PDRB Provinsi Jambi mencapai angka sebesar 23.476.564 juta rupiah, kemudian pada tahun 2015 PDRB Provinsi Jambi naik kembali sebesar 25. 678.445 juta rupiah, disusul tahun 2016 PDRB Provinsi Jambi kembali mengalami peningkatan sebasar 27.309.654 juta rupiah, dan terakhir pada tahun 2017 PDRB Provinsi Jambi kembali naik dengan angka sebesar 28.101.342 juta rupiah.

Menurut Mankiw (2006), teori upah adalah upah yang tinggi dapat mempertahankan tenaga kerja (karyawan) yang ingin keluar dari sektor usaha tidak akan menerima tenaga kerja yang baru dengan cepat tanpa keahlian dan pengalaman yang dimilikinya. Dengan upah yang tinggi perusahaan dapat meningkatkan kualitas rata-rata karyawan, apabila upah diturunkan maka para pekerja dapat berhenti dari perusahaan dan beralih kepada sektor usaha yang memberi intensif yang tinggi. Hal ini akan mempengaruhi seseorang untuk menganggur dalam waktu tertentu untuk mencari pekerjaan terbaik dengan asumsi akan mendapatkan upah tinggi. Jika tenaga kerja menetapkan upah tertentu sebagai upah minimum yang diterima, maka jika seluruh upah yang ditawarkan besarnya dibawah tingkat upah tersebut maka seserang akan menolak mendapatkan upah tersebut.

Upah minimum di Provinsi Jambi pada periode 2000-2017 selalu mengalami kenaikan pada setiap tahunnya. Pada periode 5 tahun terakhir, yaitu pada tahun 2013 upah minimum mencapai Rp. 1.142.500, kemudian pada tahun 2014 mengalami kenaikan sebesar Rp. 1.502.300, selanjutnya pada tahun 2015 naik kembali sebesar Rp. 1.710.000, lalu pada tahun 2016 naik sebesar Rp. 1.906.650, dan 2017 upah minimum mengalami kenaikan kembali hingga Rp. 2.063.000.

Menurut Boediono (1994: 155), definisi singkat dari inflasi adalah kecenderungan pada harga-harga untuk menaik secara umum dan terus menerus. Kenaikan harga dari satu atau dua barang saja tidak disebut inflasi. Syarat adanya kecenderungan menaik yang terus menerus juga harus digaris-bawahi. Kenaikan hargaharga karena misalnya: musiman, menjelang hari raya, bencana, dan sebagainya yang sifatnya hanya sementara tidak disebut inflasi.

Inflasi di Provinsi Jambi pada periode 5 tahun terakhir, yaitu pada tahun 2013 mencapai 0,4\%, kemudian pada tahun 2014 inflasi di Provinsi Jambi mengalami kenaikan yang mencapai 2,61\%, selanjutnya pada tahun 2015 inflasi di Provinsi Jambi mengalami penurunan sebesar $1,43 \%$, selanjutnya pada tahun 2016 kembali mengalami penurunan sebesar $0,36 \%$, dan pada tahun 2017 mengalami sedikit kenaikan yaitu sebesar $0,38 \%$.

Investasi adalah penanaman modal untuk satu atau lebih aktif yang dimiliki biasanya berjangka panjang dengan harapan mendapatkan keuntungan dimana yang akan datang sebagai kompensasi secara professional atas penundaan komsumsi, dampak inflasi, dan resiko yang ditanggung. Keputusan investasi dapat dilakukan individu, dari investasi tersebut dapat berupa capital gain/loss dan yield, investasi dapat dilakukan dalam bentuk investasi pada aspek fisik (ral asset) dan investasi pada asset financial (financial asset) (Sukirno, 2004). 
Selama periode 5 tahun terakhir, investasi (PMDN) di Provinsi Jambi selalu mengalami kenaikan pada setiap tahunnya. Pada tahun 2013, investasi (PMDN) mencapai Rp. 25.170.266,59, kemudian pada tahun 2014 investasi(PMDN) naik sebesar Rp. 28.418.185,16, lalu pada tahun 2015 investasi(PMDN) naik kembali sebesar Rp. 31.996.708,96, pada tahun 2016 investasi(PMDN) naik kembali sebesar Rp. 35.881.108,94, dan pada tahun 2017 naik kembali sebesar Rp. 36.101.341,23.

Peningkatan angkatan kerja baru yang lebih besar dibandingkan dengan lapangan kerja yang tersedia terus menunjukkan jurang (gap) yang terus membesar. Kondisi tersebut semakin membesar setelah krisis ekonomi. Dengan adanya krisis ekonomi tidak saja jurang antara antara peningkatan angkatan kerja baru dengan penyediaan lapangan kerja baru dengan penyediaan lapangan kerja yang rendah terus makin dalam, tetapi juga terjadi pemutusan hubungan kerja (PHK). Sehingga tingkat pengangguran dari tahun ke tahun terus semakin tinggi (Amir, 2007).

Selama periode 5 tahun terakhir tingkat partisipasi angkatan kerja di Prvinsi Jambi pada setiap tahunnya bersifat fluktuatif. Pada tahun 2013 TPAK Provinsi Jambi sebesar 62,65 persen, tahun 2014 TPAK Provinsi Jambi mengalami kenaikan sebear 65,59 persen, kemudian pada tahun 2015 TPAK Provinsi Jambi kembali mengalami kenaikan sebesar 66,14 persen, lalu pada tahun 2016 TPAK Provinsi Jambi mengalami kenaikan kembali sebesar 67,54 persen, namun pada tahun 2017 TPAK Provinsi Jambi mengalami sedikit penerunan yaitu sebesar 67,52 persen.

Berdasarkan latar belakang tersebut, penelitian ini bertujuan untuk menganalisis: (1) Perkembangan timgkat pengangguran terbuka di Provinsi Jambi; dan (2) Faktorfaktor apa yang mempengaruhi mempengaruhi tingkat pengangguran di Provinsi Jambi.

\section{METODE}

Dalam penelitian ini data yang digunakan adalah data sekunder, dalam rentang waktu tahun 2000-2017 meliputi data data pengangguran terbuka Provinsi Jambi, data PDRB Provinsi Jambi, data upah Provinsi Jambi, data inflasi Provinsi Jambi, data investasi Provinsi Jambi, dan data TPAK Provinsi Jambi. Sumber data yang digunakan dalam penelitian ini berasal dari Badan Pusat Statistik (BPS) Provinsi Jambi.

Untuk menjawab rumusan masalah pertama besarnya perkembangan diketahui dengan menggunakan rumus berikut:

$$
\text { TPT }=\frac{\sum \mathrm{PT}}{\sum \mathrm{AK}} \times 100 \%
$$

Dimana:

TPT : Tingkat pengangguran terbuka

PT : Pengangguran terbuka

AK : Angkatan Kerja

Untuk menjawab permasalahan kedua faktor-faktor yang mempengaruhi pengangguran terbuka di Provinsi Jambi menggunakan rumus sebagai berikut:

$$
\text { TPT }=\beta_{0}+\beta_{1} \text { PDRB }+\beta_{2} \text { UMP }+\beta_{3} \text { INF }+\beta_{4} \text { INV }+\beta_{5} \text { TPAK }+u
$$

Dimana:

$$
\begin{array}{ll}
\text { TPT } & =\text { Tingkat Pengangguran Terbuka }(\%) \\
\text { PDRB } & =\text { Pertumbuhan Ekonomi (Juta Rupiah) } \\
\text { UMP } & =\text { Upah }(\mathrm{Rp}) \\
\text { INF } & =\text { Inflasi }(\%)
\end{array}
$$




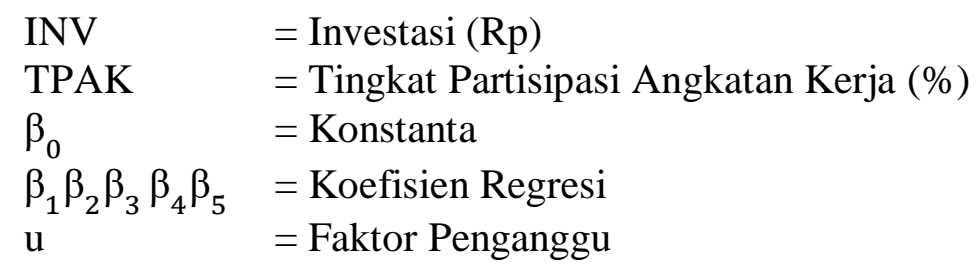

\section{Uji Statistik}

\section{Uji Simultan (Uji F)}

Uji $\mathrm{F}$ dilakukan untuk mengetahui pengaruh variabel bebas (X) secara keseluruhan terhadap variabel terikat (Y). Kesimpulan uji $\mathrm{F}$ dapat diperoleh dengan membandingkan antara nilai $\mathrm{F}$ probabilita dengan nilai $\mathrm{F}$ pada tingkat keyakinan tertentu. Pengujian ini dilakukan dengan rumus sebagai berikut:

$$
F_{\text {hitung }}=\frac{\frac{R 2}{K}-1}{(1-R 2)(n-K)}
$$

Dimana:

R2 = Koefisien Determinan

$\mathrm{k} \quad=$ Jumlah variabel bebas

$\mathrm{n} \quad=$ Jumlah sampel

Bila F-hitung > F-tabel, maka $\mathrm{H}_{0}$ dittolak, berarti secara bersama-sama variabel bebas $(\mathrm{X})$ berpengaruh secara nyata dan signifikan terhadap variabel terikat (Y). Bila Fhitung < F-tabel, maka $\mathrm{H}_{0}$ diterima, berarti secara Bersama-sama variabel bebas (X) tidak berpengaruh secara nyata terhadap variabel terikat $(\mathrm{Y})$.

\section{Uji Parsial (Uji T)}

Uji t dilakukan untuk mengetahui pengaruh variabel bebas $(\mathrm{X})$ terhadap variabel terikat (Y), kesimpulan hasil uji t dilakukan dengan membandingkan nilai t hitung dengan $t$ tabel. Pengujian ini di lakukan dengan menggunakan rumus sebagai berikut:

$$
t_{\text {hitung }}=\frac{\beta \mathrm{i}}{\operatorname{Se}(\beta \mathrm{i})}
$$

Dimana:

$\beta \mathrm{i}=$ Elastiitas variabel ke (i)

$\mathrm{Se} \beta \mathrm{i}=$ Standar Error

Bila $t_{\text {hitung }}>t_{\text {tabel }}$ berdasarkan tingkat keyakinan tertentu, maka $\mathrm{H}_{0}$ ditolak, berarti tiap-tiap variabel berpengaruh secara nyata terhadap variabel terikat. Bila $t_{\text {hitung }}<t_{\text {tabel }}$, berdasarkan tingkat keyakinan tertentu, maka $\mathrm{H}_{0}$ diterimsa, berarti tiaptiap variabel bebas tidak berpengaruh secara nyata terhadap variabel terikat.

\section{Koefisien Determinasi $\left(\mathbf{R}^{2}\right)$}

Untuk melihat dan mengetahui besarnya sumbangan variabel independent terhadap variabel dependent, maka digunakan analisis varian dengan perhitungan determinasi dengan menggunakan model sebagai berikut (Damodar Gujarati, 1999):

$$
\mathrm{R}^{2}=\mathrm{r}^{2} \mathrm{X} 100 \%
$$

Dimana:

$\mathrm{R}^{2} \quad=$ Koefisien determinasi

$\mathrm{r} \quad=$ Nilai koefisien korelasi

Nilai $\mathrm{R}^{2}$ ini menunjukkan seberapa besar variabel independent mampu 
menjelaskan variabel dependent. Kemudian untuk melihat keeratan hubungan antara variabel independent dengan variabel dependent dilakukan dengan mengambil akar dari $\mathrm{R}^{2}$ sehingga di dapat $\mathrm{R}$ yang semakin rendah mendekati 1 menandakan bahwa hubungan antara variabel independent dengan variabel dependent semakin erat.

\section{HASIL DAN PEMBAHASAN}

\section{Perkembangan pengangguran terbuka di Provinsi Jambi}

Berdasarkan tabel 1 dapat diketahui perkembangan tingkat pengangguran terbuka di Provinsi Jambi selama tahun 2000-2017 mengalami perkembangan yang fluktuatif dengan rata-rata perkembangan sebesar 0,50 persen. Perkembangan tingkat pengangguran terbuka di Provinsi Jambi tertinggi terjadi pada tahun 2005 sebesar 8,32 persen hal ini kemungkinan dikarenakan para pencari kerja sulit untuk mendapat pekerjaan dikarenakan kurangnya lapangan pekerjaan dan memilih untuk menganggur dari pada bekerja dengan upah yang rendah. Sedangkan perkembangan tingkat pengangguran terbuka di Provinsi Jambi terendah ada pada tahun 2006 sebesar -4,15 persen. Hal ini disebabkan karena pada tahun tersebut jumlah pengangguran terbuka mengalami penurunan dari tahun-tahun sebelumnya.

Tabel 1. Perkembangan tingkat pengangguran terbuka di Provinsi Jambi Tahun 20002017

\begin{tabular}{cccc}
\hline Tahun & $\begin{array}{c}\text { Jumlah Pengangguran } \\
\text { Terbuka (Jiwa) }\end{array}$ & $\begin{array}{c}\text { Tingkat Pengangguran } \\
\text { Terbuka }(\boldsymbol{\%})\end{array}$ & $\begin{array}{c}\text { Perkembangan } \\
(\boldsymbol{\%})\end{array}$ \\
\hline 2000 & 57.400 & 3,68 & - \\
2001 & 60.240 & 5,61 & 4,94 \\
2002 & 67.092 & 5,78 & 1,13 \\
2003 & 76.659 & 6,50 & 1,42 \\
2004 & 73.108 & 6,04 & 4,63 \\
2005 & 133.964 & 10,74 & 8,32 \\
2006 & 78.264 & 6,62 & $-4,15$ \\
2007 & 76.090 & 6,22 & $-2,77$ \\
2008 & 66.371 & 5,14 & $-1,27$ \\
2009 & 73.904 & 5,54 & 1,13 \\
2010 & 72.792 & 5,08 & $-1,50$ \\
2011 & 60.169 & 4,02 & $-1,73$ \\
2012 & 42.296 & 3,22 & $-2,97$ \\
2013 & 70.361 & 4,84 & 6,63 \\
2014 & 79.784 & 5,08 & 1,33 \\
2015 & 70.349 & 4,34 & $-1,18$ \\
2016 & 67.671 & 4.00 & $-3,80$ \\
2017 & 66.816 & 3,87 & $-1,27$ \\
\hline
\end{tabular}

Sumber: Badan Pusat Statistik Provinsi Jambi, 2018 (diolah)

\section{Perkembangan Produk Domestik Regional Bruto (PDRB) di Provinsi Jambi}

Produk Domestik Regional Bruto sebagai salah satu indikator ekonomi memuat berbagai instrumen ekonomi yang di dalamnya terlihat jelas keadaan makro ekonomi suatu daerah dengan petumbuhan ekonominya, income per kapita dan berbagai instrumen ekonomi lainnya. Pada tabel 2 terlihat bahwa perkembangan PDRB Provinsi Jambi dari tahun 2000-2017 mengalami peningkatan setiap tahunnya dengan nilai rata- 
rata pertumbuhan sebesar 6,07 persen. Perkembangan yang paling tinggi terjadi pada tahun 2015 sebesar 9,37 persen, hal ini terjadi dikarenakan memadainya infrastruktur yang telah dilakukan pada tahun sebelumnya yang membuat jalannya perekonomian di Provinsi Jambi membaik. Dan perkembangan yang terendah terjadi di tahun 2017 yaitu sebesar 2,89 persen selama kurun waktu dari tahun 2005-2008 pertumbuhan ekonomi Provinsi Jambi semakin tahun semakin meningkat dari 5,57 persen di tahun 2005 dan di tahun 2006 menjadi 5,89 persen, di tahun 2007 mencapai 6,82 sampai dengan tahun 2008 terus meningkat menjadi 7,15 persen, dan ditahun-tahun berikutnya pertumbuhan ekonomi berfluktuatif, hingga pada tahun 2017 pertumbuhan ekonomi di Provinsi Jambi mengalami penurunan menjadi sebesar 2,89 persen.

Tabel 2. Perkembangan PDRB Provinsi Jambi Tahun 2000-2017

\begin{tabular}{ccc}
\hline Tahun & PDRB (Juta Rupiah) & Perkembangan (\%) \\
\hline 2000 & 9.569 .242 & - \\
2001 & 10.205 .592 & 6,65 \\
2002 & 10.803 .423 & 5,86 \\
2003 & 11.343 .279 & 5,00 \\
2004 & 11.953 .885 & 5,38 \\
2005 & 12.619 .972 & 5,57 \\
2006 & 13.363 .620 & 5,89 \\
2007 & 14.275 .161 & 6,82 \\
2008 & 15.296 .726 & 7,15 \\
2009 & 16.274 .907 & 6,39 \\
2010 & 17.471 .685 & 7,35 \\
2011 & 18.963 .518 & 7,54 \\
2012 & 20.373 .533 & 7,44 \\
2013 & 21.979 .277 & 6,83 \\
2014 & 23.476 .564 & 6,81 \\
2015 & 25.678 .445 & 9,37 \\
2016 & 27.309 .654 & 6,35 \\
2017 & 28.101 .342 & 2,89 \\
\hline
\end{tabular}

Sumber: Badan Pusat Statistik Provinsi Jambi, 2018 (diolah)

\section{Perkembangan upah minimum di Provinsi Jambi}

Dari tabel 3 dapat diketahui bahwa upah di Provinsi Jambi selalu mengalami peningkatan dari tahun 2000-2017. Upah di Provinsi Jambi tahun 2000 sebesar Rp.170.000, pada tahun 2001 upah di Provinsi Jambi naik sebesar Rp. 245.000, pada tahun 2002 upah di Provinsi Jambi naik sebesar Rp. 304.000 merupakan perkambangan upah tertinggi yakni sebesar 28,29 persen, hal ini dikarenakan pada tahun 2000 Indonesia sudah mulai bangkit dari krisis moneter yang melanda termasuk juga Provinsi Jambi. Krisis moneter di tahun 1998 berdampak pada perkembangan tingkat upah dan penerima tenaga kerja sehingga pada tahun 2000 ketika perekonomian mulai pulih, tingkat upah di Provinsi Jambi menjadi lebih baik. Sedangkan perkembangan upah di Provinsi Jambi terendah terjadi pada tahun 2017, dimana perkembangannya sebesar 8.2 persen, hal ini dikarenakan rendahnya produktivitas dan kecilnya produk yang di hasilkan. Rata-rata perkembangan upah di Provinsi Jambi selama periode 2000-2017 sebesar 15,10 persen. 
Tabel 3. Perkembangan upah minimum Provinsi Jambi Tahun 2000-2017

\begin{tabular}{ccc}
\hline Tahun & Upah $(\mathbf{R p )}$ & Perkembangan (\%) \\
\hline 2000 & 173.000 & - \\
2001 & 245.000 & 41,62 \\
2002 & 304.000 & 24,08 \\
2003 & 390.000 & 28,29 \\
2004 & 425.000 & 8,97 \\
2005 & 495.000 & 14,12 \\
2006 & 563.000 & 16,08 \\
2007 & 658.000 & 16,87 \\
2008 & 724.000 & 10,03 \\
2009 & 800.000 & 10,50 \\
2010 & 900.000 & 12,50 \\
2011 & 1.028 .000 & 14,22 \\
2012 & 1.142 .500 & 11,14 \\
2013 & 1.300 .000 & 13,79 \\
2014 & 1.502 .300 & 15,56 \\
2015 & 1.710 .000 & 13,83 \\
2016 & 1.906 .650 & 11,50 \\
2017 & 2.063 .000 & 8,20 \\
\hline
\end{tabular}

Sumber: Badan Pusat Statistik, 2018 (diolah)

\section{Perkembangan inflasi Provinsi Jambi}

Pada tabel 4 dapat dilihat perkembangan inflasi di Provinsi Jambi tahun 20002017 rata-rata sebesar 0,86\%. Pada tahun 2000 tingkat inflasi di Provinsi Jambi yaitu sebesar 8,40\%, pada tahun 2004 inflasi berkurang sebesar 7,25\%, perkembangan mengalami peningkatan sebesar 9,12\% dari tahun sebelumnya. Dan pada tahun 2007 inflasi sebesar 7,42\%, mengalami penurunan perkembangan sebesar $-3,53 \%$, setelah itu di tahun 2011 inflasi di Provinsi Jambi mengalami penurunan dari tahun sebelumnya sebesar 2,76\% dan perkembangannya pun ikut mengalami penurunan sebesar $-7,30 \%$, dan tahun 2017 kembali lagi mengalami penurunan yaitu mencapai 2,76\% dengan perkembangan yang menurun sebesar $1,20 \%$.

Tingkat inflasi mempunyai hubungan positif atau negatif terhadap jumlah pengangguran. Apabila tingkat inflasi yang dihitung adalah inflasi yang terjadi pada harga-harga secara umum, maka tingginya tingkat inflasi yang terjadi akan berakibat pada peningkatan pada tingkat bunga (pinjaman). Inflasi juga merupakan suatu masalah bagi ekonomi makro yang apabila tidak segera ditangani akan menyebabkan ketidakstabilan perekonomian yang pada akhirnya hanya akan memperburuk kinerja perekonomian suatu Negara. Kestabilan nilai mata uang, baik inflasi maupun nilai tukar sangat penting untuk mendukung pembangunan ekonomi yang berkelanjutan dan meningkatkan kesejahteraan masyarakat. Kenaikan harga dari satu atau dua barang saja tidak disebut inflasi, kecuali bila kenaikan tersebut meluas kepada (mengakibatkan kenaikan) sebagian besar dari harga barang-barang lain. Inflasi adalah suatu keadaan yang ditimbulkan oleh tidak adanya keseimbangan antara permintaan barang-barang dan persediaannya, yaitu permintaan melebihi persediaan dan semakin besar perbedaan itu semakin besar bahaya yang ditimbulkan oleh inflasi bagi kesehatan ekonomi (Soesastro, 2005). 
Tabel 4. Perkembangan inflasi di Prvinsi Jambi Tahun 2000-2017

\begin{tabular}{ccc}
\hline Tahun & Inflasi & Perkembangan (\%) \\
\hline 2000 & 8,40 & - \\
2001 & 10,11 & 2,03 \\
2002 & 12,62 & 2,48 \\
2003 & 3,79 & $-6,99$ \\
2004 & 7,25 & 9,12 \\
2005 & 16,50 & 12,75 \\
2006 & 10,66 & $-3,53$ \\
2007 & 7,42 & $-3,03$ \\
2008 & 11,57 & 5,59 \\
2009 & 1,85 & $-8,40$ \\
2010 & 10,25 & 12,40 \\
2011 & 2,76 & $-7,30$ \\
2012 & 4,22 & 5,28 \\
2013 & 7,12 & 6,87 \\
2014 & 4,10 & $-4,24$ \\
2015 & 2,82 & $-3,12$ \\
2016 & 1,25 & $-5,56$ \\
2017 & 2,76 & 1,20 \\
\hline
\end{tabular}

Sumber: Badan Pusat Statistik, 2018 (diolah)

\section{Perkembangan investasi (PMDN) di Provinsi Jambi}

Pada tabel 5 dapat digambarkan perkembangan nvestasi PMDN di Provinsi Jambi pada tahun 2000 sebanyak 729.000.000.000 milyar rupiah dari tahun sebelumnya, di tahun 2004 investasi PMDN bertambah sebanyak 9.090.812.68 milyar rupiah dan mengalami peningkatan terhadap perkembangan sebesar 1,52\% dari tahun sebelumnya, 2007 investasi PMDN kembali bertambah sebesar 9.225.342.11 milyar rupiah, tetapi hanya mengalami perkembangan sebesar 1,21\%, pada tahun 2011 investasi PMDN kembali mengalami peningkatan sebesar 14.433.096.24 milyar rupiah mengalami perkembangan sebesar 5,53\% dari tahun sebelumnya, di tahun 2017 Investasi PMDN mengalami peningkatan sebesar 36.101.341.23 milyar rupiah mengalami perkembangan sebesar 0,61\% dari tahun sebelumnya. Dapat di ketahui bahwa perkembangan investasi yang tertinggi di tahun 2001 sebesar 9,18\% hal ini menyebabkan pengangguran terbuka mengalami penurunan pada tahun tersebut, dan perkembangan investasi terendah di tahun 2005 sebesar $-6,84 \%$ hal ini menyebabkan meningkatnya pengangguran terbuka pada tahun tersebut. Rata-rata investasi PMDN di Provinsi Jambi dari tahun 2000-2017 sebesar 2,18\%.

Besar kecilnya investasi yang terjadi di masyarakat akan sangat mempengaruhi besar kecilnya kesempatan kerja yang tercipta dalam masyarakat tersebut. Adanya investasi akan meningkatkan kegiatan produksi sehingga akan membuka kesempatan kerja baru. Adanya kesempatan kerja baru akan menyebabkan berkurangnya jumlah pengangguran, tetapi sebaliknya jika investasi tidak di tingkatkan maka produksi tidak akan meningkat sehingga kesempatan kerja tidak berkembang maka akan berdampak terhadap pengangguran (Mulyadi, 2000). Jadi antara investasi dan pengangguran terdapat hubungan negatif. Namun apabila investasi yang ditanamkan bersifat padat modal, maka kenaikan investasi tidak berpengaruh terhadap pasar tenaga kerja. 
Tabel 5. Perkembangan investasi (PMDN) Provinsi Jambi Tahun 2000-2017

\begin{tabular}{ccc}
\hline Tahun & $\begin{array}{c}\text { Investasi PMDN } \\
\text { (Milyar Rupiah) }\end{array}$ & Perkembangan (\%) \\
2000 & 729.000 .000 .000 & - \\
2001 & 7.425 .610 .91 & 9,18 \\
2002 & 7.887 .116 & 6,21 \\
2003 & 7.887 .116 & 0,00 \\
2004 & 9.090 .812 .68 & 1,52 \\
2005 & 8.468 .661 .80 & $-6,84$ \\
2006 & 9.114 .985 .14 & 7,63 \\
2007 & 9.225 .342 .11 & 1,21 \\
2008 & 9.316 .214 .15 & 0,98 \\
2009 & 9.573 .410 .17 & 2,76 \\
2010 & 9.611 .608 .19 & 0,39 \\
2011 & 14.433 .096 .24 & 5,53 \\
2012 & 19.933 .975 .83 & 3,81 \\
2013 & 25.170 .266 .59 & 2,62 \\
2014 & 28.418 .185 .16 & 1,29 \\
2015 & 31.996 .708 .96 & 1,25 \\
2016 & 35.881 .108 .94 & 1,21 \\
2017 & 36.101 .341 .23 & 0,61 \\
\hline
\end{tabular}

Sumber: Badan Pusat Statistik, 2018 (diolah)

\section{Perkembang tingkat partisipasi angkatan kerja Provinsi Jambi}

TPAK merupakan indikator yang biasa digunakan untuk menganalisa partisipasi angkatan kerja. Menurut Badan Pusat Statistik (BPS) tingkat partisipasi angkatan kerja adalah penduduk yang termasuk bukan angkatan kerja, penduduk usia kerja (15 tahun atau lebih) yang masih sekolah, mengurus rumah tangga, atau melaksanakan kegiatan lainnya selain kegiatan pribadi. Dari tabel di bawah diperoleh bahwa selama periode tahun 2000-2017 Tingkat Partisipasi Angkatan Kerja Provinsi Jambi mengalami peningkatan rata-rata sebesar 0,14 persen pertahunnya. Adapun jumlah TPAK tertinggi tercatat pada tahun 2005 yaitu mencapai 68,69 persen dengan perkembangan sebesar 2,14 persen. Selanjutnya pada tahun 2006 TPAK mengalami penurunan terbesar selama 18 tahun terakhir yaitu mencapai 64,26 persen dengan pekembangan sebesar $-6,45$ persen.

TPAK merupakan indikator yang biasa digunakan untuk menganalisa partisipasi angkatan kerja. Menurut Badan Pusat Statistik (BPS), tingkat partisipasi angkatan kerja adalah penduduk yang termasuk bukan angkatan kerja, penduduk usia kerja (15 tahun atau lebih) yang masih sekolah, mengurus rumah tangga, atau melaksanakan kegiatan lainnya selain kegiatan pribadi. Penduduk yang termasuk angkatan kerja adalah penduduk usia kerja (15 tahun atau lebih) yang bekerja, atau punya pekerjaan namun sementara tidak bekerja dan pengangguran. Penduduk yang termasuk bukan angkatan kerja adalah penduduk usia kerja (15 tahun atau lebih) yang masih sekolah, mengurus rumah tangga atau melaksanakan kegiatan lainnya selain kegiatan pribadi. Pada tabel dibawah ini dijelaskan perkembangan Tingkat Partisipasi Angkatan Kerja periode tahun 2000-2017. 
Tabel 6. Perkembangan TPAK di Provinsi Jambi Tahun 2000-2017

\begin{tabular}{ccc}
\hline Tahun & TPAK & Perkembangan (\%) \\
\hline 2000 & 65.65 & - \\
2001 & 67.68 & 3,09 \\
2002 & 68.00 & 0,47 \\
2003 & 67.91 & -0.13 \\
2004 & 67.25 & $-0,97$ \\
2005 & 68.69 & 2,14 \\
2006 & 64.26 & $-6,45$ \\
2007 & 65.18 & 1,43 \\
2008 & 65.95 & 1,18 \\
2009 & 66.65 & 1,06 \\
2010 & 66.38 & $-0,41$ \\
2011 & 67.67 & 1,94 \\
2012 & 65.07 & $-3,48$ \\
2013 & 62.65 & $-3,72$ \\
2014 & 65.59 & 4,69 \\
2015 & 66.14 & 0,84 \\
2016 & 67.54 & 1,34 \\
2017 & 67.52 & 0,02 \\
\hline
\end{tabular}

Sumber: Badan Pusat Statistik, 2018 (diolah)

Faktor-faktor yang mempengaruhi prngangguran terbuka di Provinsi Jambi

Pengujian ini menggunakan regresi linier berganda untuk mengetahui seberapa besar pengaruh variabel bebas terhadap variabel terikat. Pengujian ini menggunakan aplikasi Eviews 9, berdasarkan pengujian statistik diperoleh model persamaan regresi sebagai berikut:

Tabel 7. Hasil pengujian regresi linier berganda

\begin{tabular}{crrrr}
\hline \hline Variable & Coefficient & \multicolumn{1}{l}{ Std. Error } & t-Statistic & \multicolumn{1}{c}{ Prob. } \\
\hline C & -56.96980 & 18.86814 & -3.019365 & 0.0107 \\
PDRB & -30.24434 & 9.651550 & -3.133625 & 0.0086 \\
UMP & 15.96216 & 4.722059 & 3.380339 & 0.0055 \\
INF & 0.145369 & 0.081073 & 1.793060 & 0.0982 \\
INV & -1.694997 & 0.948483 & -1.787062 & 0.0992 \\
TPAK & 0.244277 & 0.164605 & 1.484019 & 0.1636 \\
\hline \hline R-squared & 0.751689 & Mean dependent var & 5.351111 \\
Adjusted R-squared & 0.648226 & S.D. dependent var & 1.681854 \\
S.E. of regression & 0.997517 & Akaike info criterion & 3.094106 \\
Sum squared resid & 11.94048 & Schwarz criterion & 3.390897 \\
Log likelihood & -21.84695 & Hannan-Quinn criter. & 3.135029 \\
F-statistic & 7.265298 & Durbin-Watson stat & 1.574567 \\
Prob(F-statistic) & 0.002402 & & \\
\hline \hline
\end{tabular}

Sumber: Data diolah, 2019 
Berdasarkan hasil pengujian Tabel 7, maka dapat ditulis persamaan regresi sebagai berikut:

$Y=\beta_{\circ}+\beta_{1} X_{1}+\beta_{2} X_{2}+\beta_{3} X_{3}+\beta_{4} X_{4}+\beta_{5} X_{5}+\varepsilon$

Dari hasil perhitungan statistik dapat diketahui nilai koefisien tiap tiap variabel dari persamaan regresi linier berganda, dapat diketahui besarnya pengaruh yang diberikan tiap-tiap variabel independen terhadap variabel dependen. Besarnya nilai koefisien regresi dari setiap variabel independen adalah sebagai berikut:

\section{Produk Domestik Regional Bruto (PDRB)}

Dari hasil regresi menunjukkan bahwa PDRB mempunyai pengaruh negatif yang signifikan terhadap tingkat pengangguran terbuka di Provinsi Jambi. Hal ini terlihat dari nilai koefisien sebesar -30.24434 dan nilai probabilita t-hitung PDRB sebesar 0.0086. Hal ini berarti terjadi kenaikan tingkat PDRB sebesar 1 persen akan diikuti dengan penurunan tingkat pengangguran terbuka sebanyak 30.24434 persen. Hal ini menunjukkan bahwa setiap peningkatan 1 juta rupiah PDRB maka pengangguran terbuka di Provinsi Jambi mengalami penurunan.

\section{Upah Minimum Provinsi}

Dari hasil regresi menunjukkan bahwa upah memiliki pengaruh positif dan signifikan terhadap pengangguran terbuka di Provinsi Jambi. Hal ini terlihat dari nilai koefisien tingkat upah sebesar 15.96216 dengan nilai probabilitas t-hitung sebesar 0.0055. Artinya apabila upah meningkat 1 persen maka tingkat pengangguran terbuka akan mengalami penurunan sebesar 15.96216 persen. Hal ini berarti dengan adanya kenaikan upah akan menambah permintaan tenaga kerja dan permintaan ini akan memenuhi penawaran tenaga kerja di Provinsi Jambi, maka akan menurunkan jumlah pengangguran terbuka di Provinsi Jambi.

\section{Inflasi}

Dari hasil regresi menunjukkan bahwa inflasi mempunyai pengaruh positif dan signifikan terhadap pengangguran terbuka di Provinsi Jambi. Hal ini terlihat dari nilai koefisien tingkat inflasi sebesar 0.145369 dengan nilai probabilita t-hitung sebesar 0.0982. Artinya apabila inflasi meningkat 1 persen maka tingkat pengangguran terbuka akan mengalami penurunan sebesar 0.145369 persen. Hal ini berarti dengan adanya kenaikan inflasi maka pengangguran terbuka di Provinsi Jambi akan mengalami penurunan.

\section{Investasi}

Dari hasil regresi menunjukkan bahwa investasi mempunyai pengaruh negatif dan signifikan terhadap pengangguran terbuka di Provinsi Jambi. Hal ini terlihat dari koefisien investasi sebesar -1.694997 dengan nilai probabilitas t-hitung sebesar 0.0992. Artinya apabila investasi meningkat 1 persen, maka tingkat pengangguran terbuka akan mengalami penurunan sebesar 1.694997 persen. Hal ini berarti semakin tinggi investasi maka pengangguran terbuka di Provinsi Jambi akan menurun.

\section{Tingkat Partisipasi Angkatan Kerja}

Dari hasil regresi menunjukkan bahwa TPAK berpengaruh positif namun tidak signifikan terhadap pengangguran terbuka di Provinsi Jambi. Hal ini terlihat dari koefisien TPAK sebesar 0.244277 dengan probabilitas t-hitung sebesar 0.1636. Artinya perubahan yang terjadi pada tingkat partisipasi angkatan kerja tidak selalu 
mengakibatkan berubahnya tingkat pengangguran terbuka, karena tingkat partisipasi angkatan kerja yang tinggi belum tentu menjamin pengangguran terbuka berkurang.

\section{Variabel PDRB}

Uji t-statistik untuk variabel PDRB terhadap tingkat pengangguran terbuka di Provinsi Jambi, dapat dilihat bahwa nilai t hitung sebesar -3.133625 dengan probabilitas variable PDRB sebesar 0.0086 atau lebih kecil dari $\alpha=0.10(0.0086<0.10)$ maka Ho ditolak dan $\mathrm{H} \alpha$ diterima. Dari hasil tersebut dapat disimpulkan bahwa variabel PDRB secara individu memiliki pengaruh signifikan terhadap pengangguran terbuka di Provinsi Jambi.

\section{Variabel upah minimum}

Uji t-statistik untuk Upah Minimum Provinsi (UMP) dapat dilihat bahwa nilai t hitung sebesar 3.380339 dengan probabilitas variabel upah minimum sebesar 0.0055 atau lebih kecil dari $\alpha=0.10(0.0055<0.10)$ maka Ho ditolak dan $\mathrm{H} \alpha$ diterima. Dari hasil tersebut dapat disimpulkan bahwa variabel upah minimum secara individu memiliki pengaruh signifikan terhadap pengangguran terbuka di Provinsi Jambi.

\section{Variabel inflasi}

Uji t-statistik untuk variabel inflasi (INF) dapat dilihat bahwa nilai t hitung sebesar 1.793060 dengan probabilitas variabel inflasi sebesar 0.0982 atau lebih kecil dari nilai $\alpha=0.10(0.0982<0.10)$, maka Ho ditolak dan H $\alpha$ diterima. Dari hasil tersebut dapat disimpulkan bahwa variabel inflasi secara individu memiliki pengaruh signifikan terhadap pengangguran terbuka di Provinsi Jambi.

\section{Variabel investasi}

Uji t-statistik untuk variabel investasi (INV) dapat dilihat bahwa t hitung sebesar -1.787062 dengan probabilitas variabel investasi sebesar 0.0992 atau lebih kecil dari $\alpha=$ $0.10(0.0992<0.10)$, maka Ho ditolak dan $\mathrm{H} \alpha$ diterima. Dari hasil tersebut dapat disimpulkan bahwa variabel investasi secara individual berpengaruh signifikan terhadap pengangguran terbuka di Provinsi Jambi.

\section{Variabel Tingkat Partisipasi Angkatan kerja (TPAK)}

Uji t-statistik untuk variabel TPAK dapat dilihat bahwa $t$ hitung sebesar 1.484019 dengan probabilitas variable TPAK sebesar 0.1636 atau lebih besar dari $\alpha=$ $0.10(0.1636>0.10)$, maka Ho diterima dan $\mathrm{H} \alpha$ ditolak. Dari hasil tersebut dapat disimpulkan bahwa variabel TPAK tidak berpengaruh signifikan terhadap pengangguran terbuka di Provinsi Jambi.

\section{KESIMPULAN DAN SARAN Kesimpulan}

Rata-rata perkembangan tingkat pengangguran terbuka di Provinsi Jambi sebesar 0,50 persen setiap tahunnya. Rata-rata perkembangan PDRB sebesar 6,07 persen setiap tahunnya, rata-rata perkembangan upah minimum Provinsi sebesar 15,10 persen setiap tahunnya, rata-rata perkembangan inflasi sebesar 0,86 persen setiap tahunnya, rata-rata perkembangan investasi sebesar 2,18 persen setiap tahunnya, dan rata-rata perkembangan TPAK sebesar 0,14 persen setiap tahunnya. 


\section{Saran}

Disarankan pemerintah mendorong pertumbuhan ekonomi dengan cara salah satunya membuka pintu investasi sehingga banyak orang berusaha membuka lapangan kerja, caranya yaitu berinvestasi sektor riil misalnya: sektor produksi, property, perkebunan, jasa dan lain-lain.

\section{DAFTAR PUSTAKA}

Amir, Amri. (2010). Pengaruh Inflasi dan Pertumbuhan Ekonomi Terhadap Pengangguran di Indonesia: Jambi.

Badan Pusat Statistik (BPS). (2017). Perkembangan UMP Provinsi Jambi 2000-2017. BPS Provinsi Jambi. BPS: Jambi.

Bada Pusat Statistik (BPS). (2017). Ketenagakerjaan Provinsi Jambi Tahun 2000-2017. BPS Provinsi Jambi. BPS: Jambi.

Boediono. (1994). Ekonomi Moneter Seri Sinopsis Pengantar Ilmu Ekonomi Moneter. BPFE: Yogyakarta.

Gujarati, Damodar. (1999). Ekonometrika Dasar. Erlangga: Jakarta.

Mankiw, N. Gregory. (2006). Teori Makro Ekonomi. Ghalia Indonesia: Jakarta.

Mulyadi. (2000). Akuntansi Biaya, Aditya Media: Yogyakarta.

Nanga, Muana. (2001). Makro Ekonomi, Teori, Masalah, Dan Kebijakan. PT. Raja Grafindo Persada: Jakarta.

Soesastro, H. (2005). Pemikiran dan Permasalahan Ekonomi di Indonesia Dalam Setengah Abad Terakhir. Jilid 1. Kanisius: Jakarta.

Sukirno, Sadono. (2004). Pengantar Teori Makro Ekonomi. PT Raja Grafindo Persada: Jakarta.

Tadoro, Michael P. (2013). Pembangunan Ekonomi. Edisi kesebelas. Erlangga: Jakarta. 